Click www.researchjournal.co.in/online/subdetail.html to purchase.

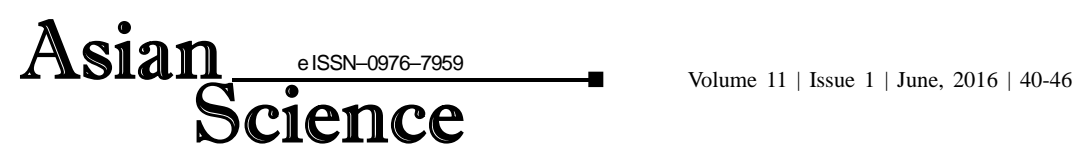

DOI : 10.15740/HAS/AS/11.1/40-46

Visit us | www.researchjournal.co.in

RESEARCH PAPER

\title{
Fertilizer industry life cycle analysis
}

\author{
ANDUKURI RAJ SHRAVANTHI* AND K. MAHENDRAN \\ Department of Agricultural and Rural Management, Tamil Nadu Agricultural University, COIMBATORE (T.N.) INDIA
}

\begin{abstract}
Life cycle is basically a concept relating to the different stages an industry will go through, from the first product entry to its eventual decline. A form of fundamental analysis involving the process of making investment decisions based on the different stages an industry is at during a given point in time. The specific objectives of the study were to study the evolution of fertilizer industry, to identify the life cycle stages in fertilizer firms and to compare the life cycle phases of older players in the industry to the recently founded ones. Secondary data such as financial data was collected from money control in 2013 and the company details were collected from the annual reports of the firm available in the firm's websites. Cluster analysis was used for grouping the firms and charts such as radar charts and scatter plots were used for analyzing the life cycle stages of the fertilizer companies. The total production of fertilizers in India is around 341.09 million tons in 2012. The annual output of fertilizer industry is around 121.10 lakh million tons. From the analysis of radar charts and scatter plots we can conclude that the older firms are in between a shakeout and maturity phase, while the younger firms are in growth phase and on a whole fertilizer industry in India is in growing phase.
\end{abstract}

Key Words : Life cycle analysis, Business cycle analysis, Industry life cycle analysis, Organizational life cycle analysis

View point paper : Shravanthi, Andukuri Raj and Mahendran, K. (2016). Fertilizer industry life cycle analysis. Asian Sci., 11 (1): 40-46, DOI : 10.15740/HAS/AS/11.1/40-46.

\footnotetext{
* Author for correspondence

Andukuri Raj Shravanthi, Department of Agricultural and Rural Management, Tamil Nadu Agricultural University, COIMBATORE (T.N.) INDIA
} 